\title{
Transfer of Pseudomonas aminovorans (den Dooren de Jong 1926) to Aminobacter gen. nov. as Aminobacter aminovorans comb. nov. and Description of Aminobacter aganoensis sp. nov. and Aminobacter niigataensis sp. nov.
}

\author{
TEIZI URAKAMI, ${ }^{1 *}$ HISAYA ARAKI, ${ }^{2}$ HIROMI OYANAGI,${ }^{2}$ KEN-ICHIRO SUZUKI, ${ }^{3}$ AND KAZUO KOMAGATA ${ }^{4}$ \\ Biochemicals Division, Mitsubishi Gas Chemical Co., Seavans-N Building, 1-2-1, Shibaura, Minato-ku, Tokyo 105, ${ }^{2}$ \\ Niigata Research Laboratory, Mitsubishi Gas Chemical Co., Niigata 950-31, ${ }^{2}$ Japan Collection of Microorganisms, \\ The Institute of Physical and Chemical Research, Wacho-shi, Saitama 351-01, ${ }^{3}$ and Institute of \\ Applied Microbiology, The University of Tokyo, Bunkyo-ku, Tokyo $113,{ }^{4}$ Japan
}

\begin{abstract}
We compared non-methane-, non-methanol-, and methylamine-utilizing bacteria, including Pseudomonas aminovorans, a tetramethylammonium-utilizing bacterium, and an $N, N$-dimethylformamide-utilizing bacterium. These bacteria are gram-negative, nonsporeforming, subpolarly flagellated, rod-shaped organisms. Reproduction occurs by budding. The DNA base compositions are 62 to $64 \mathrm{~mol} \%$ guanine plus cytosine. The cellular fatty acids contain a large amount of $C_{18: 1}$ acid. The major hydroxy acid is 3-OH $C_{12: 0}$ acid. The major ubiquinone is ubiquinone Q-10. These bacteria are clearly separated from authentic Pseudomonas species (Pseudomonas fluorescens rRNA group) on the basis of utilization of methylamine, morphological and chemotaxonomic characteristics, DNA-DNA homology, and rRNA-DNA homology. They were divided into three subgroups on the basis of their physiological characteristics and DNA-DNA homology data. A new genus, Aminobacter, and three new species, Aminobacter aminovorans comb. nov., Aminobacter aganoensis sp. nov., and Aminobacter niigataensis sp. nov., are proposed. The type species of Aminobacter gen. nov. is $A$. aminovorans, with type strain JCM 7852. The type strain of A. aganoensis is strain TH-3 (= JCM 7854), and the type strain of A. niigataensis is strain DM-81 (= JCM 7853).
\end{abstract}

Although a large number of methane- and methylamineutilizing bacteria and a large number of methanol- and methylamine-utilizing bacteria have been described $(23,29$, 43-54), only a few non-methane-, non-methanol-, and methylamine-utilizing have been found to date $(4,10,13,22,29$, 32, 40-42). Pseudomonas aminovorans (4), Pseudomonas sp. strain MA (32), and Pseudomonas sp. strain MS (22) have been reported to be gram-negative methylamine-utilizing bacteria. These three bacteria were distinguished from methane- and methanol-utilizing bacteria on the basis of their failure to utilize methanol and methane. De Ley et al. (5) studied the rRNA cistron similarities of Pseudomonas and Pseudomonas-like strains and reported that the type strain of $P$. aminovorans was actually a member of the Rhizobium loti rRNA branch and not a member of the genus Pseudomonas. Furthermore, Green and Gillis (12) observed the budding multiplication of $P$. aminovorans strains and discussed the relationship of these organisms to $R$. loti and Blastobacter species. However, these authors did not make formal taxonomic proposals concerning Pseudomonas aminovorans. Recently, Tsuji et al. (39) described the results of a $16 \mathrm{~S}$ rRNA sequence analysis performed to determine the phylogenetic relationships among methylotrophs; in this analysis they included methanol- and methylamine-utilizing Methylophilus, Methylobacterium, and Hyphomicrobium strains, but non-methane-, non-methanol-, and methylamine-utilizing bacteria were not studied.

Previously, we described the biodegradation of tetramethylammonium hydroxide (TMAH) and $N, N$-dimethylformamide (DMF) by bacteria $(40,42)$; in this work strains $\mathrm{TH}-3^{\mathrm{T}}$ $\left(\mathrm{T}=\right.$ type strain), $\mathrm{DM}-81^{\mathrm{T}}$, and $\mathrm{TH}-15$, Paracoccus amino-

\footnotetext{
* Corresponding author.
}

philus (41, 42), and Paracoccus aminovorans (41, 42) were described. Strains TH $-3^{\mathrm{T}}$ and DM- $81^{\mathrm{T}}$ were non-methane-, non-methanol-, monomethylamine-, dimethylamine-, and trimethylamine-utilizing, nonsporeforming, gram-negative, subpolarly flagellated, rod-shaped organisms with a ubiquinone Q-10 system, a cellular fatty acid composition which included a large amount of $\mathrm{C}_{18: 1}$ acid, a hydroxy fatty acid composition which included a large amount of 3-hydroxy $\mathrm{C}_{12: 0}$ acid, and a DNA base composition ranging from 62 to $64 \mathrm{~mol} \%$ guanine plus cytosine $(\mathrm{G}+\mathrm{C})(40,42)$. These characteristics were identical for Pseudomonas aminovorans JCM $7852^{\mathrm{T}}$, Pseudomonas sp. strain MA, and Pseudomonas sp. strain MS, as reported previously $(47,48)$.

In this study, we characterized five methylamine-utilizing bacteria, including strains $\mathrm{TH}-3^{\mathrm{T}}$ and $\mathrm{DM}-81^{\mathrm{T}}$, and clarified the differentiation of these organisms from authentic Pseudomonas species; in this paper we propose the transfer of Pseudomonas aminovorans to a new genus, Aminobacter, as Aminobacter aminovorans and the establishment of two new species, Aminobacter aganoensis and Aminobacter niigataensis.

\section{MATERIALS AND METHODS}

Bacterial strains. The strains which we studied are listed in Table 1. Strain $\mathrm{TH}-3^{\mathrm{T}}$ was isolated as a TMAH-utilizing bacterium, and strain $\mathrm{DM}-81^{\mathrm{T}}$ was isolated as a DMFutilizing bacterium $(40,42)$. Pseudomonas aminovorans JCM 7852 $2^{\mathrm{T}}\left(=\mathrm{NCIB} 9039^{\mathrm{T}}=\right.$ NCTC $10684^{\mathrm{T}}=$ ATCC $23314^{\mathrm{T}}$ ) (4), Pseudomonas sp. strain ATCC 23819 (= strain MA = NCIB 11590) (32), and Pseudomonas sp. strain ATCC 25262 (= strain MS = NCIB 11591) (22) are non-methane-, non-methanol-, and methylamine-utilizing bacteria $(47,48)$.

Pseudomonas diminuta JCM $2788^{\mathrm{T}}$ (= ATCC $11568^{\mathrm{T}}=$ 
TABLE 1. Differentiating physiological characteristics of methylamine-utilizing bacteria

\begin{tabular}{|c|c|c|c|c|c|c|c|c|}
\hline \multirow[b]{2}{*}{ Strain } & \multirow{2}{*}{$\begin{array}{l}\text { Nitrate } \\
\text { reduction }\end{array}$} & \multirow{2}{*}{$\begin{array}{l}\text { Growth in } \\
\text { peptone } \\
\text { water }\end{array}$} & \multicolumn{5}{|c|}{ Utilization of: } & \multirow{2}{*}{$\begin{array}{l}\text { Production } \\
\text { of acid from } \\
\text { L-arabinose } \\
\text { oxidatively }\end{array}$} \\
\hline & & & Dimethylamine & Formamide & $\begin{array}{l}N \text {-Methyl- } \\
\text { formamide }\end{array}$ & DMF & TMAH & \\
\hline $\begin{array}{l}\text { Pseudomonas } \\
\text { aminovorans JCM } \\
7852^{\mathrm{T}}\end{array}$ & - & + & - & - & - & - & - & + \\
\hline $\begin{array}{l}\text { Pseudomonas sp. strain } \\
\text { ATCC } 23819\end{array}$ & - & + & - & - & - & - & - & + \\
\hline $\begin{array}{l}\text { Pseudomonas sp. strain } \\
\text { ATCC } 25262\end{array}$ & - & + & - & - & - & - & - & + \\
\hline $\mathrm{TH}-3^{\mathrm{T}}$ & $\mathrm{w}^{a}$ & w or - & + & - & - & - & + & - \\
\hline $\mathrm{DM}-81^{\mathrm{T}}$ & w & w or - & + & w & + & + & - & - \\
\hline
\end{tabular}

${ }^{a} \mathrm{w}$, weak.

IAM $\left.1513^{\mathrm{T}}\right)$, Pseudomonas vesicularis IFO $12165^{\mathrm{T}}(=$ ATCC $11426^{\mathrm{T}}=$ IAM $\left.12105^{\mathrm{T}}\right)$, Sphingomonas paucimobilis (Pseudomonas paucimobilis $[17,59])$ IFO $13935^{\mathrm{T}}(=$ ATCC $29837^{\mathrm{T}}=$ NCTC $11030^{\mathrm{T}}$ ), Sphingomonas paucimobilis $($ Flavobacterium devorans $[17,59])$ NCIB 8195 (= ATCC 10829 $=$ DSM $30198=$ CCM 72), Sphingomonas capsulata $($ Fla vobacterium capsulatum $[17,59])$ NCIB $9890^{\mathrm{T}}$ (= ATCC $14666^{\mathrm{T}}=$ IFO $12533^{\mathrm{T}}$ ), Pseudomonas aeruginosa JCM $5962^{\mathrm{T}}\left(=\right.$ ATCC $10145^{\mathrm{T}}=$ NCIB $8295^{\mathrm{T}}=$ NCTC $10332^{\mathrm{T}}=$ NRRL B-771 ${ }^{\mathrm{T}}$ ), and Pseudomonas fluorescens NCIB $9046^{\mathrm{T}}$ $\left(=\right.$ ATCC $13525^{\mathrm{T}}=\mathrm{CCM} 2115^{\mathrm{T}}=\mathrm{DSM} 50090^{\mathrm{T}}=\mathrm{JCM}$ $5963^{\mathrm{T}}$ ) were used as reference strains. Strains TH- ${ }^{\mathrm{T}}$ and $\mathrm{DM}-81^{\mathrm{T}}$ and the three methylamine-utilizing bacteria resembled Pseudomonas diminuta, Pseudomonas vesicularis, $S$. paucimobilis, and $S$. capsulata on the basis of their cellular fatty acid compositions and quinone systems $(16,25,26,58$, 59). Pseudomonas aeruginosa and Pseudomonas fluorescens are typical species of the genus Pseudomonas. The bacterial strains were maintained on PYG agar (pH 7.0) (41).

Identification methods. PYG agar was used for preculturing and as the basal medium for strains $\mathrm{TH}-3^{\mathrm{T}}$ and $\mathrm{DM}-81^{\mathrm{T}}$, Pseudomonas aminovorans, Pseudomonas sp. strain ATCC 23819, and Pseudomonas sp. strain ATCC 25262. Unless otherwise stated, the strains were cultivated aerobically in PYG broth at $30^{\circ} \mathrm{C}$. Cell form, Gram reaction, motility, and multiplication were determined by using cells grown on PYG agar. Motility was observed by using the hanging drop method. Flagellar morphology and multiplication were determined by the staining method of Toda (37), using a light microscope, and by using an electron microscope when the organisms were negatively stained with $2 \%$ phosphotungstic acid ( $\mathrm{pH} 7.0)$. Granules of poly- $\beta$-hydroxybutyrate in cells cultivated in medium containing $0.5 \%$ (wt/vol) DL- $\beta$-hydroxy- $n$-butyric acid (sodium salt) were stained by using the methods of Burdon (3). Biochemical and physiological characteristics were examined by previously described methods (41). Utilization of carbon compounds was determined by growth in liquid basal medium B (43) after 3 weeks of cultivation, and methanol was replaced with other carbon compounds as previously described (41). TMAH was added at a concentration of $0.15 \%$.

Utilization of methanol, monomethylamine, dimethylamine, trimethylamine, trimethylamine- $N$-oxide, formamide, $N$-methylformamide, DMF, and TMAH by reference strains was determined as described above and previously (41).

Cellular fatty acid and hydroxy fatty acid compositions. Cells of reference strains cultivated aerobically for 1 day were used for the cellular fatty acid analysis. Cellular fatty acid composition and hydroxy fatty acid composition were determined as described previously (49).

Quinone and quinone homologs. Cells of reference strains that were cultivated aerobically for 2 days were used for the quinone analysis. Quinone systems were determined as described previously (47). In the abbreviations used for ubiquinones, $Q$ indicates ubiquinone, and the number indicates the number of isoprenoid units in the side chain (e.g., Q-9, Q-10, etc.).

DNA base composition. Cells that were cultivated aerobically for 2 days were used for the DNA analysis. DNA was extracted by using the method of Saito and Miura (31), and the $\mathrm{G}+\mathrm{C}$ content was determined by reversed-phase highperformance liquid chromatography as described by Tamaoka and Komagata (36).

DNA-DNA hybridization. DNA-DNA hybridization was carried out at $68^{\circ} \mathrm{C}$ by using the method of Kaneko et al. (21). The DNAs of strains TH-3 ${ }^{\mathrm{T}}$ and DM-81 ${ }^{\mathrm{T}}$, Pseudomonas aminovorans JCM $7852^{\mathrm{T}}$, Pseudomonas diminuta JCM $2788^{\mathrm{T}}$, and $S$. paucimobilis IFO $13935^{\mathrm{T}}$ were labeled with $\left[1^{\prime}, 2^{\prime}, 5-{ }^{3} \mathrm{H}\right] \mathrm{dCTP}$ by the nick translation method, using a type TRK 7000 kit (Amersham International plc, Amersham, United Kingdom).

\section{RESULTS}

Phenotypic characteristics of methylamine-utilizing bacteria. The methylamine-utilizing bacteria (strains $\mathrm{TH}-3^{\mathrm{T}}$ and DM-81 ${ }^{\mathrm{T}}$, Pseudomonas aminovorans JCM $7852^{\mathrm{T}}$, Pseudomonas sp. strain ATCC 23819, and Pseudomonas sp. strain ATCC 25262) were gram-negative, nonsporeforming, rodshaped, methylamine-utilizing organisms that were 0.5 to 0.9 by 1.0 to $3.0 \mu \mathrm{m}$ and had rounded ends. Nonmucoid colonies were formed on PYG, nutrient, or methylamine-containing medium. The cells occurred singly or rarely in pairs, reproduced by budding, and were motile by means of subpolar flagella. The flagella of Pseudomonas aminovorans JCM $7852^{\mathrm{T}}$ and strain DM-81 ${ }^{\mathrm{T}}$ are shown in Fig. 1. Granules of poly- $\beta$-hydroxybutyric acid were accumulated in the cells. Colonies were white to light yellow. Cells grew abundantly in nutrient broth and PYG broth. No water-soluble fluorescent pigment was produced on King B medium. The methyl red test and the Voges-Proskauer test in glucose phosphate broth (35) were negative. Indole and hydrogen sulfide were not produced. Hydrolysis of gelatin and starch was not observed. Ammonia was produced. Denitrification was negative. Litmus milk was not changed. All of the strains produced acids oxidatively from $\mathrm{D}$-arabinose, D-xylose, D-glucose, D-mannose, D-fructose, galactose, maltose, su- 

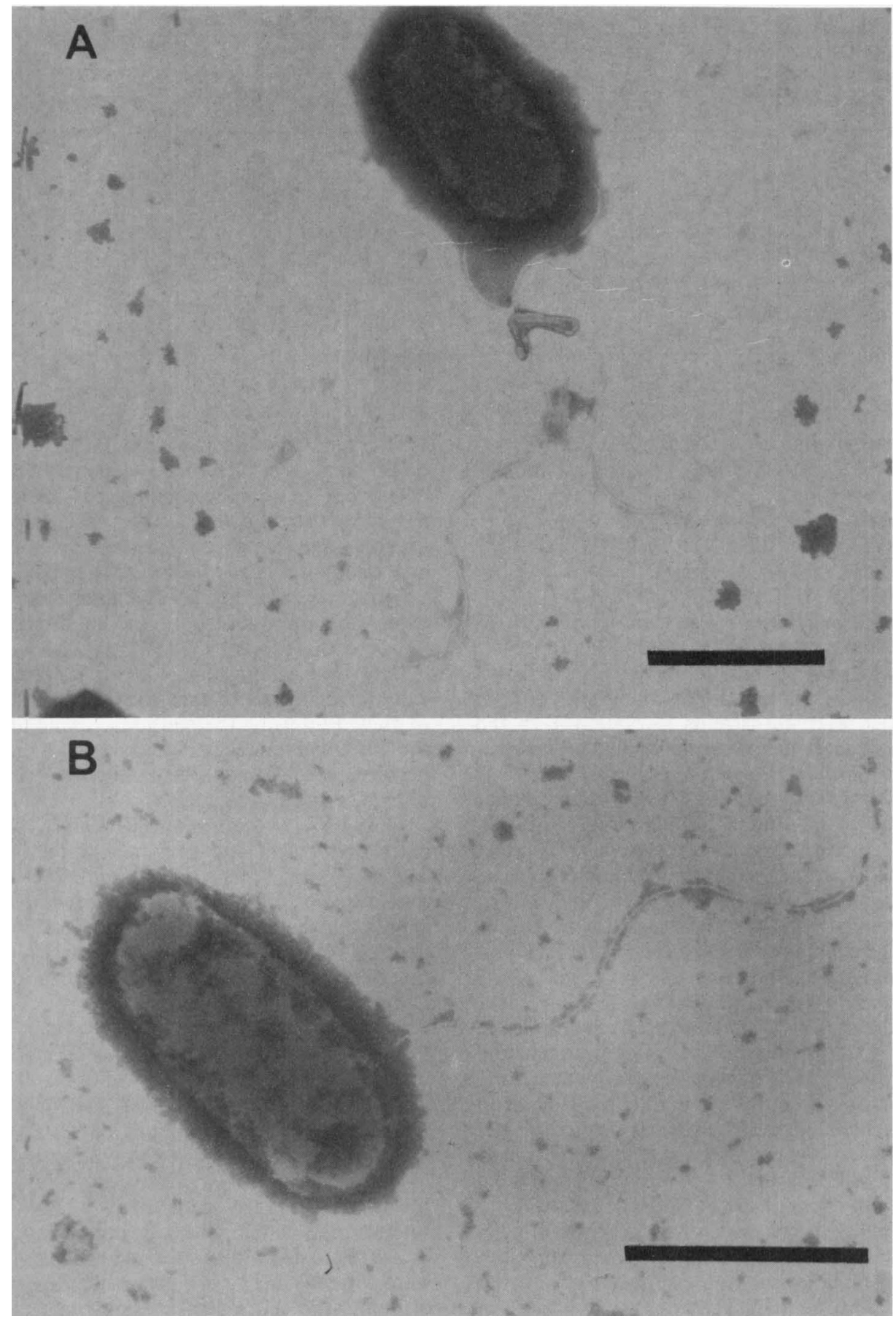

FIG. 1. Electron micrographs of negatively stained cells. Bar $=1 \mu \mathrm{m}$. (A) Pseudomonas aminovorans JCM $7852^{\mathrm{T}}$. (B) Strain DM-81 ${ }^{\mathrm{T}}$.

crose, trehalose, D-sorbitol, D-mannitol, inositol, and glycerol, but did not produce acids from lactose and soluble starch. Acids were not produced fermentatively. All strains grew at the expense of L-arabinose, D-xylose, D-glucose, D-mannose, D-fructose, D-galactose, maltose, sucrose, trehalose, D-sorbitol, D-mannitol, inositol, glycerol, succinic acid, acetic acid, monomethylamine, trimethylamine, and trimethylamine- $N$-oxide, but did not grow at the expense of lactose, soluble starch, citric acid, formic acid, ethanol, methanol, methane, or hydrogen. Growth factors were not required as an essential supplement. All strains utilized ammonia, nitrate, urea, peptone, and methylamine as nitrogen sources. Oxidase and catalase were produced, but urease was not produced. Growth was observed at $\mathrm{pH} 6.0$ to 8.0, but not at $\mathrm{pH} 5.0$ and 9.0. All strains grew at 30 and $37^{\circ} \mathrm{C}$, but not at $42^{\circ} \mathrm{C}$. Growth did not occur in the presence of $3 \% \mathrm{NaCl}(\mathrm{wt} / \mathrm{vol})$. The biochemical and physiological characteristics that differed among the methylamine-utilizing bacteria are shown in Table 1.

Utilization of $\mathbf{C}_{1}$ compounds by the reference strains. None 
TABLE 2. Cellular fatty acid compositions of methylamine-utilizing bacteria and reference strains

\begin{tabular}{|c|c|c|c|c|c|c|c|c|c|c|c|c|c|c|c|c|c|c|}
\hline \multirow{3}{*}{ Strain } & \multicolumn{18}{|c|}{ Fatty acid composition (\% of total acids) } \\
\hline & \multicolumn{9}{|c|}{ Straight-chain acids } & \multicolumn{2}{|c|}{$\begin{array}{l}\text { Cyclopro- } \\
\text { pane acids }\end{array}$} & \multicolumn{3}{|c|}{ 3-Hydroxy acids } & \multicolumn{3}{|c|}{ 2-Hydroxy acids } & \multirow{2}{*}{$\begin{array}{l}\text { Unknown } \\
\text { peak }\end{array}$} \\
\hline & $\mathrm{C}_{14: 0}$ & $C_{14: 1}$ & $C_{15: 0}$ & $C_{16: 0}$ & $C_{16: 1}$ & $C_{17 ; 0}$ & $\mathrm{C}_{18: 0}$ & $\mathrm{C}_{18: 1}$ & $C_{19: 0}$ & $\mathrm{C}_{17: 0}$ & $\mathrm{C}_{19: 0}$ & $\begin{array}{l}3-\mathrm{OH} \\
\mathrm{C}_{10: 0} \\
\end{array}$ & $\begin{array}{r}3-\mathrm{OH} \\
\mathrm{C}_{12: 0} \\
\end{array}$ & $\begin{array}{l}3-\mathrm{OH} \\
\mathrm{C}_{14: 0} \\
\end{array}$ & $\begin{array}{r}2-\mathrm{OH} \\
\mathrm{C}_{12: 0} \\
\end{array}$ & $\begin{array}{l}2-\mathrm{OH} \\
\mathrm{C}_{14: 0} \\
\end{array}$ & $\begin{array}{l}2-\mathrm{OH} \\
\mathrm{C}_{16: 0} \\
\end{array}$ & \\
\hline $\begin{array}{l}\text { Pseudomonas amino- } \\
\text { vorans } \mathrm{JCM} 7852^{\mathrm{Ta}}\end{array}$ & & & & 9.8 & 0.2 & 0.2 & 7.6 & 54.6 & & & 3.0 & & 0.3 & & & & & 22.5 \\
\hline $\begin{array}{l}\text { Pseudomonas sp. strain } \\
\quad \text { ATCC } 23819^{a}\end{array}$ & & & & 8.4 & 1.6 & & 3.4 & 64.5 & 0.2 & & 3.2 & & 0.5 & & & & & 18.2 \\
\hline $\begin{array}{l}\text { Pseudomonas sp. strain } \\
\text { ATCC } 25262^{a}\end{array}$ & & & & 7.4 & 4.2 & 0.4 & 7.7 & 53.5 & & & 4.5 & & 0.1 & & & & & 22.2 \\
\hline TH-3 $3^{\mathrm{T} b}$ & & & & 10.1 & 5.9 & & 4.3 & 70.1 & & & & & 0.7 & 0.2 & & & & 8.7 \\
\hline $\mathrm{DM}-81^{\mathrm{T} c}$ & & & & 7.3 & 6.7 & & 3.1 & 72.8 & & & & & 0.9 & & & & & 9.2 \\
\hline $\begin{array}{l}\text { Pseudomonas diminuta } \\
\text { JCM } 2788^{\mathrm{T}}\end{array}$ & 0.8 & 1.6 & 2.0 & 18.9 & 1.8 & 2.1 & 0.4 & 63.9 & & 4.5 & 1.0 & & 3.0 & & & & & \\
\hline $\begin{array}{l}\text { Pseudomonas vesicu- } \\
\text { laris IFO } 12165^{\mathrm{T}}\end{array}$ & 2.8 & 0.2 & 0.2 & 20.1 & 5.7 & 0.1 & 1.1 & 64.8 & & 0.4 & & & 4.6 & & & & & \\
\hline $\begin{array}{l}\text { S. paucimobilis IFO } \\
13935^{\mathrm{T}}\end{array}$ & 1.6 & & & 12.0 & 2.8 & & 0.8 & 68.4 & & & 0.1 & & & & & 14.2 & 0.1 & \\
\hline $\begin{array}{l}\text { S. paucimobilis NCIB } \\
8195\end{array}$ & 0.6 & & & 14.3 & 2.1 & & 1.1 & 66.9 & & & 0.1 & & & & & 14.7 & 0.2 & \\
\hline $\begin{array}{l}\text { S. capsulata NCIB } \\
9890^{\mathrm{T}}\end{array}$ & & & & 10.3 & 3.9 & & 0.5 & 73.0 & & & & & & & & 12.2 & 0.1 & \\
\hline $\begin{array}{l}\text { Pseudomonas aerugi- } \\
\text { nosa } \mathrm{JCM} 5962^{\mathrm{T}}\end{array}$ & 1.1 & & & 23.2 & 19.6 & & 0.3 & 46.8 & & 0.5 & 0.3 & 2.3 & 0.6 & & 5.3 & & & \\
\hline $\begin{array}{l}\text { Pseudomonas fluo- } \\
\text { rescens NCIB } 9046^{\mathrm{T}}\end{array}$ & 1.6 & & & 30.8 & 35.2 & & 1.5 & 22.0 & & 0.1 & 0.2 & 3.0 & 1.1 & & 4.5 & & & \\
\hline
\end{tabular}

of the reference strains utilized methanol, monomethylamine, dimethylamine, trimethylamine, trimethylamine- $N$ oxide, formamide, $N$-methylformamide, DMF, and TMAH.

Cellular fatty acid composition. The methylamine-utilizing bacteria $(40,42,49)$, Pseudomonas diminuta $\mathrm{JCM} 2788^{\mathrm{T}}$, Pseudomonas vesicularis IFO $12165^{\mathrm{T}}$, S. paucimobilis IFO $13935^{\mathrm{T}}$ and NCIB 8195 , and $S$. capsulata NCIB $9890^{\mathrm{T}}$ contained large amounts of straight-chain unsaturated $C_{18: 1}$ acid. The methylamine-utilizing bacteria did not contain straight-chain saturated $\mathrm{C}_{14: 0}$ acid, but they did contain an identical unknown peak (Table 2). Pseudomonas aeruginosa JCM $5962^{\mathrm{T}}$ and Pseudomonas fluorescens NCIB $9046^{\mathrm{T}}$ contained large amounts of straight-chain saturated $\mathrm{C}_{16: 0}$ acid and straight-chain unsaturated $\mathrm{C}_{16: 1}$ and $\mathrm{C}_{18: 1}$ acids. (Large amount was defined as $20 \%$ or more of the total acids.)

Hydroxy fatty acid composition. The methylamine-utilizing bacteria (40, 42, 49), Pseudomonas diminuta, and Pseudomonas vesicularis contained large amounts of 3-hydroxy $\mathrm{C}_{12: 0}$ acid as a proportion of the total hydroxy fatty acids. $S$. paucimobilis and $S$. capsulata contained large amounts of 2-hydroxy $\mathrm{C}_{14: 0}$ acid, and Pseudomonas aeruginosa and Pseudomonas fluorescens contained large amounts of 3-hydroxy $\mathrm{C}_{10: 0}$ and $\mathrm{C}_{12: 0}$ acids, as well as 2-hydroxy $\mathrm{C}_{12: 0}$ acid (Table 3).

Quinone system. The methylamine-utilizing bacteria (40, 42, 47), Pseudomonas diminuta, Pseudomonas vesicularis, $S$. paucimobilis, and $S$. capsulata had ubiquinone Q-10 systems (Table 3 ). In contrast, Pseudomonas aeruginosa and Pseudomonas fluorescens had ubiquinone Q-9 systems.

DNA base composition. The DNA base compositions of the methylamine-utilizing bacteria $(40,42)$ ranged from 62 to 64 mol\% G $+\mathrm{C}$ (Table 4). The DNA base composition of Pseudomonas aminovorans $26^{\mathrm{T}}$ of den Dooren de Jong (= JCM
$7852^{\mathrm{T}}$ ) was reported to be $63.2 \mathrm{~mol} \%$ by Mandel (24), but its value was determined to be $62.5 \mathrm{~mol} \%$ in this study. The difference may have been due to the methods used for determination, as Mandel used the buoyant density method. The DNA base compositions of the reference strains ranged from 60 to $67 \mathrm{~mol} \% \mathrm{G}+\mathrm{C}$.

DNA-DNA hybridization. The levels of DNA-DNA homology among the methylamine-utilizing bacteria and reference strains are shown in Table 4 . The strains tested were divided into four major groups (groups I through IV), and the similarity values between the groups were less than $20 \%$. The five methylamine-utilizing bacteria (group I) were clearly distinguished from the reference strains. Pseudomonas aminovorans, Pseudomonas sp. strain ATCC 23819, and Pseudomonas sp. strain ATCC 25262 (group I-1) exhibited high levels ( 78 to $100 \%$ ) of similarity to each other; strains TH- ${ }^{\mathrm{T}}$ (group I-2) and DM-81 ${ }^{\mathrm{T}}$ (group I-3) and the other methylamine-utilizing bacteria exhibited low levels (37 to $62 \%$ ) of similarity to each other. On the other hand, Pseudomonas diminuta and Pseudomonas vesicularis (group II) were separated clearly from the other strains. Pseudomonas diminuta (group II-1) and Pseudomonas vesicularis (group II-2) exhibited low levels (34\%) of similarity to each other. $S$. paucimobilis IFO $13935^{\mathrm{T}}$ and NCIB 8195 (group III) exhibited high levels $(84 \%)$ of similarity and were clearly separated from the other strains.

\section{DISCUSSION}

Pseudomonas sp. strain ATCC 23819 and Pseudomonas sp. strain ATCC 25262 were identified as Pseudomonas aminovorans by their phenotypic characteristics (Table 1) and by their high homology values ( 78 or $85 \%$ ) in DNA-DNA 
TABLE 3. Hydroxy fatty acid compositions and ubiquinone homologs of methylamine-utilizing bacteria and reference strains

\begin{tabular}{|c|c|c|c|c|c|c|c|c|c|c|c|}
\hline \multirow{2}{*}{ Strain } & \multicolumn{3}{|c|}{ 3-Hydroxy acid } & \multicolumn{3}{|c|}{$\begin{array}{l}\text { 2-Hydroxy acid } \\
\text { composition }^{b}\end{array}$} & \multicolumn{5}{|c|}{ Ubiquinone homolog composition ${ }^{c}$} \\
\hline & $\mathrm{C}_{10: 0}$ & $\mathrm{C}_{12: 0}$ & $\mathrm{C}_{14: 0}$ & $\mathrm{C}_{12: 0}$ & $\mathrm{C}_{14: 0}$ & $\mathrm{C}_{16: 0}$ & Q-7 & Q-8 & Q-9 & Q-10 & Q-11 \\
\hline $\begin{array}{l}\text { Pseudomonas aminovorans JCM } \\
7852^{\mathrm{Td}}\end{array}$ & & 100 & & & & & & & 2.5 & 97.0 & 0.5 \\
\hline Pseudomonas sp. strain ATCC $23819^{d}$ & & 100 & & & & & & & 5.8 & 93.7 & 0.5 \\
\hline Pseudomonas sp. strain ATCC $2526^{d}$ & & 100 & & & & & & & 6.6 & 93.2 & 0.2 \\
\hline $\mathrm{TH}-3^{\mathrm{Te}}$ & & 78.8 & 21.2 & & & & & & 0.3 & 99.7 & \\
\hline $\mathrm{DM}-81^{\mathrm{T} f}$ & & 100 & & & & & & & 1.6 & 98.4 & \\
\hline Pseudomonas diminuta JCM $2788^{\mathrm{T}}$ & 0.6 & 97.0 & 2.4 & & & & & 0.4 & 14.0 & 84.9 & 0.7 \\
\hline Pseudomonas vesicularis IFO $12165^{\mathrm{T}}$ & 0.5 & 95.2 & 4.3 & & & & & & 7.5 & 91.7 & 0.8 \\
\hline S. paucimobilis IFO $13935^{\mathrm{T}}$ & & & & & 99.3 & 0.7 & & 2.2 & 22.7 & 74.9 & 2.1 \\
\hline S. paucimobilis NCCIB 8195 & & & & & 98.7 & 1.3 & & 1.2 & 14.2 & 84.4 & 0.2 \\
\hline S. capsulata NCIB $9890^{\mathrm{T}}$ & & & & & 99.2 & 0.8 & & 1.0 & 5.6 & 92.1 & 1.3 \\
\hline Pseudomonas aeruginosa JCM $5962^{\mathrm{T}}$ & 69.9 & 30.1 & & 100 & & & 0.3 & 6.2 & 92.8 & 0.7 & \\
\hline $\begin{array}{l}\text { Pseudomonas fluorescens NCIB } \\
9_{9046^{T}}\end{array}$ & 72.7 & 27.3 & & 100 & & & & 4.0 & 92.9 & 3.1 & \\
\hline
\end{tabular}

${ }^{a}$ Expressed as a percentage of the total 3-hydroxy acids.

${ }^{b}$ Expressed as a percentage of the total 2-hydroxy acids.

cExpressed as a percentage of the total ubiquinones.

${ }^{d}$ Data from references 47 and 49.

C Data from reference 40

$f$ Data from reference 42 .

hybridization experiments (Table 4). Strains $\mathrm{TH}-3^{\mathrm{T}}$ and $\mathrm{DM}-81^{\mathrm{T}}$ should be included in the same genus to which Pseudomonas aminovorans belongs on the basis of their morphological characteristics and the following chemotaxonomic characteristics: cellular fatty acid composition $(40,42$, $49)$, hydroxy fatty acid composition $(40,42,49)$, quinone system $(40,42,47,60)$, DNA base composition $(40,42)$, and DNA-DNA homology. Pseudomonas aminovorans, which is a typical species of methylamine-utilizing bacteria, is included in Section V in Bergey's Manual of Systematic Bacteriology (27), which includes a number of Pseudomonas species whose natural relationships with well-characterized species of the genus are unknown. These methylamineutilizing bacteria were distinguished clearly from the genus Pseudomonas sensu stricto (Pseudomonas fluorescens rRNA branch [8]) on the basis of the following characteristics: motility by subpolar flagella, multiplication by budding (12), utilization of methylamine, quinone system, cellular fatty acid composition, hydroxy fatty acid composition, DNA-DNA homology, and rRNA-DNA homologies $(5,8)$. The following taxa have been reported to be gram-negative, nonpigmented, methylamine-utilizing bacteria: Methylobacillus glycogenes (46), Methylophilus methylotrophus (19), Methylovorus glucosotrophus (11), Methylophaga species (48), Hyphomicrobium species $(14,50)$, Ancylobacter aquaticus (45), Paracoccus species $(41,52)$, and Thiobacillus versutus (51). Pseudomonas aminovorans strains are distinguished from Methylobacillus, Methylophilus, Methylovorus, and Methylophaga species on the basis of multiplication mode, utilization of methanol and carbohydrates, quinone system $(44,47)$, cellular fatty acid composition $(44$ 49), hydroxy acid composition (46), and DNA base composition. Furthermore, Pseudomonas aminovorans strains metabolize $\mathrm{C}_{1}$ compounds via the serine pathway $(2,54)$ whereas Methylobacillus, Methylophilus, Methylovorus, and Methylophaga strains metabolize these compounds by

TABLE 4. DNA base compositions and DNA-DNA homologies of methylamine-utilizing bacteria and reference strains

\begin{tabular}{|c|c|c|c|c|c|c|c|}
\hline \multirow[b]{2}{*}{ Strain } & \multirow{2}{*}{$\begin{array}{l}\mathrm{G}+\mathrm{C} \\
\text { content } \\
\text { (mol\%) }\end{array}$} & \multicolumn{5}{|c|}{$\%$ of DNA-DNA homology with strain: } & \multirow{2}{*}{$\begin{array}{c}\text { DNA-DNA } \\
\text { homology } \\
\text { group }\end{array}$} \\
\hline & & $\begin{array}{r}\mathrm{JCM} \\
7852^{\mathrm{T}}\end{array}$ & $\mathrm{TH}-3^{\mathrm{T}}$ & DM- $81^{T}$ & $\begin{array}{l}\mathrm{JCM} \\
2788^{\mathrm{T}}\end{array}$ & $\underset{13935^{\mathrm{T}}}{\mathrm{IFO}}$ & \\
\hline $\begin{array}{l}\text { Pseudomonas aminovorans JCM } \\
7852^{\mathrm{T}}\end{array}$ & 62.5 & 100 & 37 & 37 & 6 & 5 & $\mathrm{I}-1$ \\
\hline Pseudomonas sp. strain ATCC 23819 & 63.2 & 78 & 45 & 44 & $\square^{a}$ & - & I-1 \\
\hline Pseudomonas sp. strain ATCC 25262 & 62.7 & 85 & 50 & 49 & - & - & I-1 \\
\hline TH-3 ${ }^{\mathbf{T}}$ & 63.8 & 58 & 100 & 60 & - & - & $\mathrm{I}-2$ \\
\hline DM- $81^{T}$ & 63.2 & 62 & 62 & 100 & - & - & $\mathrm{I}-2$ \\
\hline Pseudomonas diminuta $\mathrm{JCM} 2788^{\mathrm{T}}$ & 66.2 & 8 & - & - & 100 & 13 & II-1 \\
\hline Pseudomonas vesicularis IFO $12165^{\mathrm{T}}$ & 65.9 & 6 & - & - & 34 & 11 & II-2 \\
\hline S. paucimobilis IFO $13935^{\mathrm{T}}$ & 65.1 & 7 & - & - & 12 & 100 & III \\
\hline S. paucimobilis NCIB 8195 & 64.9 & 8 & - & - & 17 & 84 & III \\
\hline S. capsulata NCIB $9890^{\mathrm{T}}$ & 64.8 & - & - & - & - & - & \\
\hline Pseudomonas aeruginosa $\mathrm{JCM} 5962^{\mathrm{T}}$ & 65.9 & 5 & - & - & 10 & 6 & IV \\
\hline $\begin{array}{l}\text { Pseudomonas fluorescens NCIB } \\
9_{9046^{T}}\end{array}$ & 60.2 & - & - & - & - & - & \\
\hline
\end{tabular}

\footnotetext{
${ }^{a}$ - not tested.
} 
the ribulose monophosphate pathway $(11,19,46,48)$. Pseudomonas aminovorans strains are distinguished from $\mathrm{Hy}$ phomicrobium species on the basis of formation of hyphae, utilization of methanol and carbohydrates, quinone system and hydroxy acid composition (14, 47, 50). Pseudomonas aminovorans strains are distinguished from Ancylobacter species on the basis of cell shape, utilization of methanol and carbon compounds, hydroxy acid composition (49), and DNA base composition (45). Pseudomonas aminovorans strains are distinguished from Paracoccus species on the basis of morphological characteristics, utilization of carbon compounds, hydroxy acid composition (49), and rRNADNA hybridization data $(8,18)$. Pseudomonas aminovorans strains are distinguished from $T$. versutus on the basis of morphological characteristics, utilization of carbon compounds, hydroxy acid composition, and DNA base composition (51). Furthermore, Thiobacillus species are characterized as $\beta$-purple bacteria on the basis of their 16S rRNA sequences (56). On the other hand, Rhizobium and Agrobacterium species, which are related to Pseudomonas aminovorans strains as determined by rRNA-DNA hybridization $(5,8)$, are characterized as $\alpha$-purple bacteria (56). Therefore, allocation of these methylamine-utilizing bacteria to the genus Methylobacillus, Methylophilus, Methylovorus, Meth ylophaga, Hyphomicrobium, Ancylobacter, Paracoccus, or Thiobacillus is inappropriate. In 1982, Doronina et al. (9) isolated "Blastobacter aminooxidans," a budding methylamine-utilizing bacterium, from activated sludge. However, Pseudomonas aminovorans strains are distinguished from " $B$. aminooxidans" on the basis of motility, color of colonies, utilization of hydrogen and methanol, tolerance of $\mathrm{NaCl}$, hydrolysis of gelatin and starch, metabolism of $\mathrm{C}_{1}$ compounds, cellular fatty acid composition, and DNA base composition $(9,15,38)$. Furthermore, the latter species is not on the Approved Lists of Bacterial Names (33). De Ley et al. (5) showed that Pseudomonas aminovorans NCTC $10684^{\mathrm{T}}\left(=\mathrm{JCM} 7852^{\mathrm{T}}\right)$ is actually a member of the $R$. loti rRNA branch as determined by rRNA-DNA hybridization. However, Pseudomonas aminovorans strains are distinguished from $R$. loti on the basis of mucosity of colonies, utilization of methylamine, production of extracellular gum (20), hydroxy fatty acid composition (61), and thermal denaturation values versus $23 \mathrm{~S}\left[{ }^{3} \mathrm{H}\right] \mathrm{rRNA}$ of $R$. lot $i$ NZP 2037 (5, 8). Also, the failure of representative Pseudomonas aminovorans strains to reduce acetylene has been described by Green and Gillis (12). Furthermore, these methylamineutilizing bacteria were isolated from soils that were enriched with various amines, which served as sole carbon and energy sources. Therefore, allocation of these methylamine-utilizing bacteria to the genus Rhizobium is inappropriate. Green and Gillis (12) pointed out the resemblance based on phenotypic characteristics between Pseudomonas aminovorans strains and the genus Blastobacter, which contains heterotrophic rod-shaped budding bacteria that do not fix nitrogen. Although the genus Blastobacter contains Blastobacter henricii (type species), Blastobacter aggregatus, Blastobacter capsulatus, Blastobacter denitrificans, and Blastobacter natatorius as valid species $(15,34)$, no culture of the type species has been isolated (34). Furthermore, Trotsenko et al. stated in Bergey's Manual (38) that "future subdivision into two or more genera may become necessary." Pseudomonas aminovorans strains resemble $B$. aggregatus and $B$. denitrificans in motility and colony pigmentation, but are distinguished from $B$. aggregatus on the basis of production of acid from mannitol under aerobic conditions, utilization of ethanol and succinic acid, tolerance of $\mathrm{NaCl}$, and DNA base composition and from $B$. denitrificans on the basis of production of acid from mannitol under aerobic conditions, utilization of methanol, ethanol, and sucrose, tolerance of $\mathrm{NaCl}$, and denitrification. Rothe et al. (30) reported that $B$. aggregatus DSM $111^{\mathrm{T}}$ (= IFAM $\left.10003^{\mathrm{T}}\right)$ is more closely related to Agrobacterium tumefaciens DSM $30150\left(S_{\mathrm{AB}}\right.$, $0.84)$ than to Rhizobium leguminosarum ATCC $10004\left(S_{\mathrm{AB}}\right.$, 0.73 ) as determined by $16 \mathrm{~S}$ rRNA cataloging performed to determine the phylogenetic positions of these organisms. Agrobacterium tumefaciens DSM 30150 is included in Agrobacterium cluster I as determined by rRNA-DNA hybridization (6). Agrobacterium tumefaciens is more closely related to Rhizobium meliloti and $R$. leguminosarum than to $R$. lot $i$ as determined by rRNA-DNA hybridization $(5,18)$. Therefore, Pseudomonas aminovorans, which is related to $R$. loti as determined by rRNA-DNA hybridization, should be distinguished from $B$. aggregatus. Green and Gillis (12) found that Pseudomonas aminovorans differed from $B$. denitrificans NCIB $12292^{\mathrm{T}}$ on the basis of the rRNA-DNA hybridization data of Hirsch and Müller (15). Therefore, allocation of these methylamine-utilizing bacteria to the genus Blastobacter is inappropriate.

After considering the phenotypic, chemotaxonomic, and rRNA-DNA hybridization characteristics of the non-methane-, non-methanol-, and methylamine-utilizing, gram-negative, subpolarly flagellated, budding, rod-shaped organisms, we believe that it is appropriate to establish a new genus, Aminobacter, for these bacteria. The minimal characteristics for differentiating the genus Aminobacter from related genera are shown in Table 5. The DNA-DNA homology values for Pseudomonas aminovorans $\mathrm{JCM} 7852^{\mathrm{T}}$ and strains $\mathrm{TH}-3^{\mathrm{T}}$ and $\mathrm{DM}-81^{\mathrm{T}}$ were approximately 37 to $62 \%$, and these values may not be high enough to create new species. However, these strains were clearly distinguished on the basis of utilization of dimethylamine, $N$-methylformamide, DMF, and TMAH (Table 1). Therefore, we believe that strains $\mathrm{TH}-3^{\mathrm{T}}$ and DM- $81^{\mathrm{T}}$ should be separated from Pseudomonas aminovorans and from each other at the species level.

We propose that Pseudomonas aminovorans should be transferred to the new genus Aminobacter as Aminobacter aminovorans and that the following two new species should be established: Aminobacter aganoensis for strain $\mathrm{TH}-3^{\mathrm{T}}$ and Aminobacter niigataensis for strain DM- $81^{\mathrm{T}}$. The minimal characteristics for differentiating Aminobacter species are shown in Table 1.

Pseudomonas diminuta and Pseudomonas vesicularis resemble each other and are distinguished from the genus Pseudomonas sensu stricto (Pseudomonas fuorescens rRNA branch [8]) on the basis of chemotaxonomic characteristics and DNA-DNA hybridization data. These two species are members of group IV as determined by the rRNADNA hybridization analysis of Palleroni et al. (28) and are included in Section IV of the genus Pseudomonas in Bergey's Manual (27). These findings were supported by the results of the rRNA-DNA homology analyses of De Vos and De Ley (7) and De Ley et al. (5) and by the results of a partial nucleic sequence analysis of $16 \mathrm{~S}$ rRNA $(56,57,59)$. We believe that Pseudomonas diminuta and Pseudomonas vesicularis represent a new genus and elsewhere will provide a description of this new genus.

Pseudomonas paucimobilis is included in Section $\mathrm{V}$ in Bergey's Manual (27). Several authors have suggested that $F$. devorans and $F$. capsulatum resemble Pseudomonas paucimobilis $(1,8,58)$. Recently, Yabuuchi et al. proposed the new genus Sphingomonas and the new species $S$. pauci- 


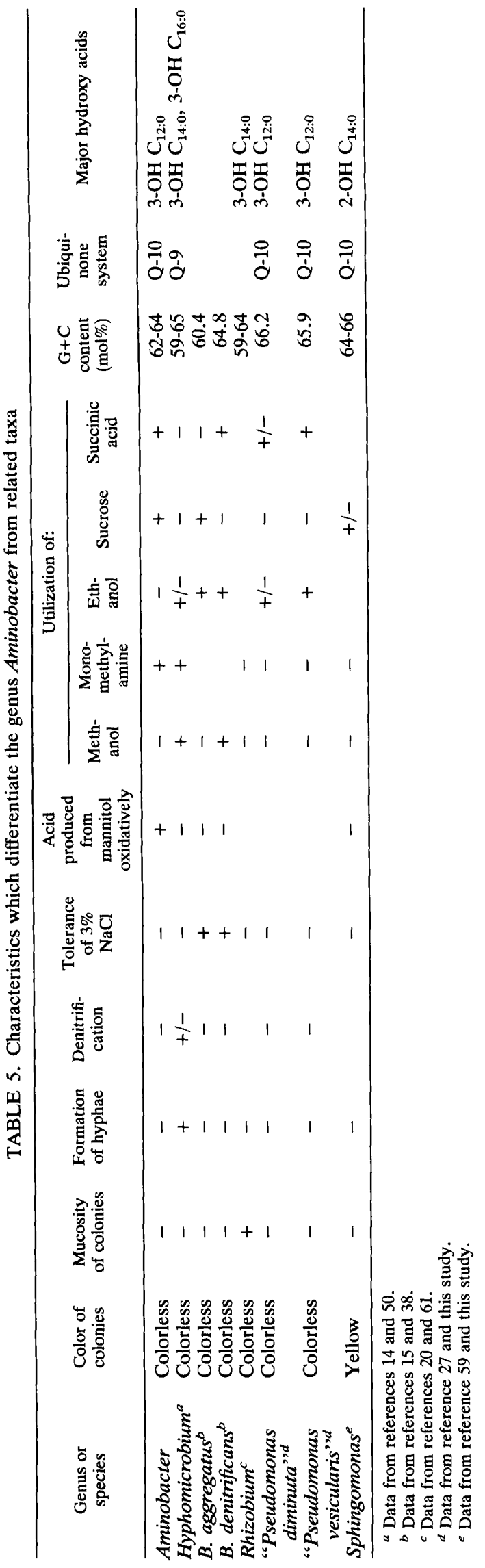

mobilis for Pseudomonas paucimobilis and $F$. devorans and the new species $S$. capsulata for $F$. capsulatum $(17,59)$. The chemotaxonomic characteristics found in this study support the proposal for the new genus Sphingomonas.

Description of Aminobacter Urakami, Araki, Oyanagi, Suzuki, and Komagata gen. nov. Aminobacter (Am.i.no.bac'ter. M.L.n. aminum, amine; M.L.n. bacter, rod, staff; M.L. masc.n. Aminobacter, amine rod). Nonsporeforming, gramnegative, rod-shaped, methylamine-utilizing organisms that are 0.5 to 0.9 by 1.0 to $3.0 \mu \mathrm{m}$ and have rounded ends. The cells occur singly (rarely in pairs) and are motile by means of subpolar flagella. Reproduction occurs by budding (12). Granules of poly- $\beta$-hydroxybutyric acid are accumulated in the cells. Colonies are white to light yellow. Cells grow abundantly in nutrient broth and PYG broth.

A water-soluble fluorescent pigment is not produced. The methyl red test and the Voges-Proskauer test are negative. Indole and hydrogen sulfide are not produced. Hydrolysis of gelatin and starch is not observed. Ammonia is produced. Denitrification is negative. Litmus milk is not changed. Acids are produced from sugars oxidatively, but not fermentatively. Monomethylamine, trimethylamine, trimethylamine- $N$-oxide, and sugars are utilized, but methanol, methane, and hydrogen are not utilized. Growth factors are not required as essential supplements. Ammonia, nitrate, urea, peptone, and methylamine are utilized as nitrogen sources. Oxidase and catalase are produced, but urease is not. Aerobic. Metabolism is strictly respiratory and not fermentative. Good growth occurs between $\mathrm{pH} 6.0$ and 8.0, but growth does not occur above $\mathrm{pH} 9.0$ and below $\mathrm{pH} 5.0$. Good growth occurs at 30 and $37^{\circ} \mathrm{C}$, but does not occur at $42^{\circ} \mathrm{C}$. Growth does not occur in the presence of $3 \%$ sodium chloride.

The DNA base composition ranges from 62 to $64 \mathrm{~mol} \%$ $\mathrm{G}+\mathrm{C}$. The cellular fatty acids include a large amount of straight-chain unsaturated $\mathrm{C}_{18: 1}$ acid. The hydroxy acids include a large amount of 3-OH $\mathrm{C}_{12: 0}$ acid. The ubiquinone system is ubiquinone Q- 10 .

The type species is Aminobacter aminovorans.

Description of Aminobacter aminovorans (den Dooren de Jong 1926) Urakami, Araki, Oyanagi, Suzuki, and Komagata comb. nov. Aminobacter aminovorans has all of the characteristics which define the genus. In addition, it has the characteristics described below. Growth occurs in peptone water. Nitrate is not reduced to nitrite. Acids are produced oxidatively from L-arabinose, D-xylose, D-glucose, D-mannose, $\mathrm{D}$-fructose, D-galactose, maltose, sucrose, trehalose, D-sorbitol, D-mannitol, inositol, and glycerol, but are not produced from lactose and soluble starch. L-Arabinose, D-xylose, D-glucose, D-mannose, D-fructose, D-galactose, maltose, sucrose, trehalose, D-sorbitol, D-mannitol, inositol, glycerol, succinic acid, acetic acid, monomethylamine, trimethylamine, and trimethylamine- $N$-oxide are utilized, but lactose, soluble starch, citric acid, formic acid, ethanol, methanol, dimethylamine, formamide, $N$-methylformamide, DMF, TMAH, methane, and hydrogen are not utilized.

The type strain is strain JCM 7852 (= NCIB $9039=$ ATCC 23314), which was isolated from soil enrichments containing various amines by de Dooren de Jong in 1926. This strain has all of the characteristics given above for the species. Its DNA base composition is $62.5 \mathrm{~mol} \% \mathrm{G}+\mathrm{C}$. The type strain has been deposited in the Japan Collection of Microorganisms, Institute of Physical and Chemical Research, as strain JCM 7852.

According to our results, Pseudomonas sp. strain ATCC 23819 (= strain MA = NCIB 11590) and Pseudomonas sp. 
strain ATCC 25262 (= strain MS = NCIB 11591) should be identified as strains of Aminobacter aminovorans.

Description of Aminobacter aganoensis Urakami, Araki, Oyanagi, Suzuki, and Komagata sp. nov. Aminobacter aganoensis (a.ga.no. en'sis. M.L. neut. adj. aganoensis, coming from the Agano River, Niigata, Japan) has all of the characteristics which define the genus. In addition, it has the characteristics described below. Poor growth occurs in peptone water. Nitrate is reduced to nitrite weakly. Acids are produced oxidatively from D-xylose, D-glucose, D-mannose, D-fructose, D-galactose, maltose, sucrose, trehalose, D-sorbitol, D-mannitol, inositol, and glycerol, but are not produced from L-arabinose, lactose, and soluble starch. Formation of acids from D-glucose, D-mannose, maltose, sucrose, trehalose, D-sorbitol, D-mannitol, and inositol is weak. L-Arabinose, D-xylose, D-glucose, D-mannose, D-fructose, D-galactose, maltose, sucrose, trehalose, D-sorbitol, D-mannitol, inositol, glycerol, succinic acid, acetic acid, monomethylamine, dimethylamine, trimethylamine, trimethylamine- $N$-oxide, and TMAH are utilized, but lactose, soluble starch, citric acid, formic acid, ethanol, methanol, formamide, $N$-methylformamide, DMF, methane, and hydrogen are not utilized. Acetic acid is utilized weakly.

The type strain is strain TH-3. Strain TH- $3^{\mathrm{T}}$ has all of the characteristics given above for the species. Its DNA base composition is $63.8 \mathrm{~mol} \% \mathrm{G}+\mathrm{C}$. This strain was isolated as a TMAH-utilizing bacterium from soil by Urakami et al. (40). The type strain has been deposited in the Japan Collection of Microorganisms, Institute of Physical and Chemical Research, as strain JCM 7854.

Description of Aminobacter niigataensis Urakami, Araki, Oyanagi, Suzuki, and Komagata sp. nov. Aminobacter niigataensis (ni.i.ga.ta. en'sis. M.L. neut. adj. niigataensis, coming from the Niigata region of Japan) has all of the characteristics which define the genus. In addition, it has the characteristics described below. Poor growth occurs in peptone water. Nitrate is reduced to nitrite weakly. Acids are produced oxidatively from D-xylose, D-glucose, D-mannose, D-fructose, D-galactose, maltose, sucrose, trehalose, D-sorbitol, D-mannitol, inositol, and glycerol, but are not produced from L-arabinose, lactose, and soluble starch. L-Arabinose, D-xylose, D-glucose, D-mannose, D-fructose, D-galactose, maltose, sucrose, trehalose, D-sorbitol, D-mannitol, inositol, glycerol, succinic acid, acetic acid, monomethylamine, dimethylamine, trimethylamine, trimethylamine$N$-oxide, $N$-methylformamide, and DMF are utilized, but lactose, soluble starch, citric acid, formic acid, ethanol, methanol, TMAH, methane, and hydrogen are not utilized. Formamide is utilized weakly.

The type strain is strain DM-81. Strain DM- $81^{\mathrm{T}}$ has all of the characteristics given above for the species. Its DNA base composition is $63.2 \mathrm{~mol} \% \mathrm{G}+\mathrm{C}$. This strain was isolated as a DMF-utilizing bacterium from soil by Urakami et al. (42). The type strain has been deposited in the Japan Collection of Microorganisms, Institute of Physical and Chemical Research, as strain JCM 7853 .

\section{REFERENCES}

1. Bauwens, M., and J. De Ley. 1981. Improvement in the taxonomy of Flavobacterium by DNA:rRNA hybridizations, p. 2731. In H. Reichenbach and O. B. Weeks (ed.), The Flavobac terium-Cytophaga groups. Verlag Chemie, Weinheim, Federal Republic of Germany.

2. Bellion, E., and L. B. Hersch. 1972. Methylamine metabolism in a Pseudomonas species. Arch. Biochem. Biophys. 153:368-374.

3. Burdon, K. L. 1946. Fatty material in bacteria and fung revealed by staining dried, fixed slide preparations. J. Bacteriol. 52:665-678.

4. De Dooren de Jong, L. E. 1927. Ueber Protaminophage Bakterien. Zentralbl. Bakteriol. Parasitenkd. Infektionskr. Hyg. Abt. 2 71:193-232.

5. De Ley, J., W. Mannheim, P. Segers, A. Lievens, M. Denyn, M. Vanhoucke, and M. Gillis. 1987. Ribosomal ribonucleic acid cistron similarities and taxonomic neighborhood of Burcella and CDC group Vd. Int. J. Syst. Bacteriol. 37:35-42.

6. De Smedt, J., and J. De Ley. 1977. Intra- and intergeneric similarities of Agrobacterium ribosomal ribonucleic acid cistrons. Int. J. Syst. Bacteriol. 27:222-240.

7. De Vos, P., and J. De Ley. 1983. Intra- and intergeneric similarities of Pseudomonas and Xanthomonas ribosomal ribonucleic acid cistrons. Int. J. Syst. Bacteriol. 33:487-509.

8. De Vos, P., A. Van Landschoot, P. Segers, R. Tytgat, M. Gillis, M. Bauwens, R. Rossau, M. Goor, B. Pot, K. Kersters, P. Lizzaraga, and J. De Ley. 1989. Genotypic relationships and taxonomic localization of unclassified Pseudomonas and Pseudomonas-like strains by deoxyribonucleic acid-ribosomal ribonucleic acid hybridization. Int. J. Syst. Bacteriol. 39:35-49.

9. Doronina, N. V., N. I. Govorukhina, and Y. A. Trotsenko. 1983. Blastobacter aminooxidans, a new species of bacteria growing autotrophically on methylated amines. Mikrobiologiya 52:709715 .

10. Ghisalba, O., P. Cevery, M. Kuenzi, and H.-P. Schar. 1985. Biodegradation of chemical waste by specialized methylotrophs, an alternative to physical methods of waste disposal. Conserv. \& Recycling 8:47-71.

11. Govorukhina, N. I., and Y. A. Trotsenko. 1991. Methylovorus, a new genus of restricted facultatively methylotrophic bacteria. Int. J. Syst. Bacteriol. 41:158-162.

12. Green, P. N., and M. Gillis. 1989. Classification of Pseudomonas aminovorans and some related methylated amine utilizing bacteria. J. Gen. Microbiol. 135:2071-2076.

13. Hampton, D., and L. J. Zatman. 1973. The metabolism to tetramethylammonium chloride by bacteria $5 \mathrm{H} 2$. Biochem. Soc. Trans. 1:667-668.

14. Hirsch, P. 1984. Genus Hyphomicrobium Stutzer and Hartleb $1898,76^{\mathrm{AL}}$, p. 1895-1904. In N. R. Krieg and J. G. Holt (ed.), Bergey's manual of systematic bacteriology, vol. 1. The Williams \& Wilkins Co., Baltimore.

15. Hirsch, P., and M. Müller. 1985. Blastobacter aggregatus sp. nov., Blastobacter capsulatus sp. nov., and Blastobacter denitrificans sp. nov., new budding bacteria from fresh water habitats. Syst. Appl. Microbiol. 6:281-286.

16. Ikemoto, S., H. Kuraishi, K. Komagata, R. Azuma, T. Suto, and H. Murooka. 1978. Cellular fatty acid composition in Pseudomonas species. J. Gen. Appl. Microbiol. 24:199-213.

17. International Journal of Systematic Bacteriology. 1990. Validation of the publication of new names and new combinations previously effectively published outside the IJSB. List no. 34 Int. J. Syst. Bacteriol. 40:320-321.

18. Jarvis, B. D. W., M. Gillis, and J. De Ley. 1986. Intra- and intergeneric similarities between the ribosomal ribonucleic acid cistrons of Rhizobium and Bradyrhizobium species and some related bacteria. Int. J. Syst. Bacteriol. 36:129-138.

19. Jenkins, O., D. Byrom, and D. Jones. 1987. Methylophilus: a new genus of methanol-utilizing bacteria. Int. J. Syst. Bacteriol. 37:446-448.

20. Jordan, D. C. 1984 . Genus I. Rhizobium Frank $1889,338^{\text {AL }}$, p. 235-242. In N. R. Krieg and J. G. Holt (ed.), Bergey's manual of systematic bacteriology, vol. 1. The Williams \& Wilkins Co., Baltimore.

21. Kaneko, T., R. Nozaki, and K. Aizawa. 1978. Deoxyribonucleic acid relatedness between Bacillus antracis, Bacillus cereus, and Bacillus thuringiensis. Microbiol. Immunol. 22:639-641.

22. Kung, H. F., and C. Wagner. 1970. Oxidation of $C_{1}$ compounds by Pseudomonas sp. MS. Biochem. J. 116:357-365.

23. Litchfield, J. H. 1977. Comparative technical and economic aspects of single-cell protein processes. Adv. Appl. Microbiol. 22:267-305.

24. Mandel, M. 1966. Deoxyribonucleic acid base composition in 
the genus Pseudomonas. J. Gen. Microbiol. 43:273-292.

25. Oyaizu, H., and K. Komagata. 1981. Chemotaxonomic and phenotypic characterization of the strains of species in the Flavobacterium-Cytophaga complex. J. Gen. Appl. Microbiol. 27:57-107.

26. Oyaizu, H., and K. Komagata. 1983. Grouping of Pseudomonas species on the basis of cellular fatty acid composition and the quinone system with special reference to the existence of 3-hydroxy fatty acids. J. Gen. Appl. Microbiol. 29:17-40.

27. Palleroni, N. J. 1984. Genus I. Pseudomonas Migula $1894,237^{\mathrm{AL}}$ (Nom. Conc. Opin. 5, Jud, Comm. 1952,237), p. 141-199. In N. R. Krieg and J. G. Holt (ed.), Bergey's manual of systematic bacteriology, vol. 1. The Williams \& Wilkins Co., Baltimore.

28. Palleroni, N. J., R. Kunisawa, R. Contopoulou, and M. Doudoroff. 1973. Nucleic acid homologies in the genus Pseudomonas. Int. J. Syst. Bacteriol. 23:333-339.

29. Quayle, J. R. 1972. The metabolism of one-carbon compounds by micro-organisms. Adv. Microb. Physiol. 7:119-203.

30. Rothe, B., A. Fischer, P. Hirsch, M. Sitting, and E. Stackebrandt. 1987. The phylogenetic position of the budding bacteria Blastobacter aggregatus and Gemmobacter aquatilis gen. nov., sp. nov. Arch. Microbiol. 147:92-99.

31. Saito, H., and K. Miura. 1963. Preparation of transforming deoxyribonucleic acid by phenol treatment. Biochim. Biophys. Acta 72:619-629.

32. Shaw, W. V., L. Tasi, and E. R. Stadtman. 1966. The enzymatic synthesis of $N$-methylglutamic acid. J. Biol. Chem. 241:935945.

33. Skerman, V. B. D., V. McGoman, and P. H. A. Sneath (ed.). 1980. Approved lists of bacterial names. Int. J. Syst. Bacteriol. 30:225-420.

34. Sly, L. I. 1985. Emendation of the genus Blastobacter Zavarzin 1961 and description of Blastobacter natatorius sp. nov. Int. J. Syst. Bacteriol. 35:40-45.

35. Smith, N. R., R. E. Gordon, and F. E. Clark. 1952. Aerobic sporeforming bacteria. Agricultural Monograph no. 16. United States Department of Agriculture, Washington, D. C.

36. Tamaoka, J., and K. Komagata. 1984. Determination of DNA base composition by reversed-phase high-performance liquid chromatography. FEMS Microbiol. Lett. 25:125-128.

37. Toda, T. 1923. A staining method for bacterial flagella. Nihon Iji Shinpo 283:113.

38. Trotsenko, Y. A., N. V. Doronina, and P. Hirsch. 1989. Genus Blastobacter Zavarzin 1961,962 AL, p. 1963-1968. In J. T. Saley, M. P. Bryant, N. Pfennig, and J. G. Holt (ed.), Bergey's manual of systematic bacteriology, vol. 3. The Williams \& Wilkins Co., Baltimore.

39. Tsuji, K., H. C. Tsien, R. S. Hanson, S. R. DePalma, R. Scholtz, and S. LaRoche. 1990. 16S ribosomal RNA sequence analysis for determination of phylogenetic relationship among methylotrophs. J. Gen. Microbiol. 136:1-10.

40. Urakami, T., H. Araki, and H. Kobayashi. 1990. Isolation and identification of tetramethylammonium-biodegrading bacteria. J. Ferment. Bioeng. 68:41-44.

41. Urakami, T., H. Araki, H. Oyanagi, K. Suzuki, and K. Komagata. 1990. Paracoccus aminophilus sp. nov, and Paracoccus aminovorans sp. nov., which utilize $N, N$-dimethylformamide. Int. J. Syst. Bacteriol. 40:287-291.

42. Urakami, T., H. Kobayashi, and H. Araki. 1990. Isolation and identification of $N, N$-dimethylformamide-biodegrading bacteria. J. Ferment. Bioeng. 68:45-47.

43. Urakami, T., and K. Komagata. 1984. Protomonas, a new genus of facultatively methylotrophic bacteria. Int. J. Syst. Bacteriol. 34:188-201.

44. Urakami, T., and K. Komagata. 1984. Cellular fatty acid composition and quinone system in methane-utilizing bacteria and methylamine-utilizing bacteria, p. 123-133. In R. L. Crawford and R. S. Hanson (ed.), Microbial growth on $\mathrm{C}_{1}$ compounds The Proceedings of the Fourth International Symposium. American Society for Microbiology, Washington, D. C.

45. Urakami, T., and K. Komagata. 1986. Methanol-utilizing Ancylobacter strains and comparison of their cellular fatty acid compositions and quinone systems with those of Spirosoma Flectobacillus, and Runella species. Int. J. Syst. Bacteriol. 36:415-421.

46. Urakami, T., and K. Komagata. 1986. Emendation of Methylobacillus Yordy and Weaver 1977, a genus for methanol-utilizing bacteria. Int. J. Syst. Bacteriol. 36:502-511.

47. Urakami, T., and K. Komagata. 1986 . Occurrence of isoprenoid compounds in gram-negative methanol-, methane-, and methylamine-utilizing bacteria. J. Gen. Appl. Microbiol. 32:317-341.

48. Urakami, T., and K. Komagata. 1987. Characterization of species of marine methylotrophs of the genus Methylophaga. Int. J. Syst. Bacteriol. 37:402-406.

49. Urakami, T., and K. Komagata. 1987. Cellular fatty acid composition with special reference to the existence of hydroxy fatty acids in gram-negative methanol-, methane-, and methylamineutilizing bacteria. J. Gen. Appl. Microbiol. 33:135-165.

50. Urakami, T., and K. Komagata. 1987. Characterization and identification of methanol-utilizing Hyphomicrobium species and a comparison with species of Hyphomonas and Rhodomicrobium. J. Gen. Appl. Microbiol. 33:521-542.

51. Urakami, T., J. Tamaoka, K. Suzuki, and K. Komagata. 1989 Acidomonas gen. nov., incorporating Acetobacter methanolicus as Acidomonas methanolica comb. nov. Int. J. Syst. Bacteriol. 39:50-55.

52. Urakami, T., J. Tamaoka, K. Suzuki, and K. Komagata. 1989 Paracoccus alcaliphilus sp. nov., an alkaliphilic and facultatively methylotrophic bacterium. Int. J. Syst. Bacteriol. 39:116121

53. Urakami, T., and I. Yano. 1989. Methanol-utilizing Mycobacterium strains isolated from soils. J. Gen. Appl. Microbiol. 35:125-133.

54. Wagner, C., and M. E. Levitch. 1975. Enzymes involved in the assimilation of one-carbon units by Pseudomonas MS. J. Bacteriol. 122:905-910.

55. Whittenbury, R., H. Dalton, M. Ecclestone, and H. L. Reed. 1975. The different types of methane-oxidizing bacteria and some of their more unusual properties, p. 1-9. In The Organizing Committee (ed.), Microbial growth on $\mathrm{C}_{1}$ compounds. Proceedings of the First International Symposium. Society of Fermentation Technology, Osaka, Japan.

56. Woese, C. R. 1987. Bacterial evolution. Microbiol. Rev. 51:221271.

57. Woese, C. R., P. Blanz, and C. M. Hahn. 1984. What isn't a pseudomonad: the importance of nomenclature in bacterial classification. Syst. Appl. Microbiol. 5:179-195.

58. Yabuuchi, E., E. Tanimura, A. Ohyama, I. Yano, and A. Yamamoto. 1979. Flavobacterium devorans ATCC 10829: a strain of Pseudomonas paucimobilis. J. Gen. Appl. Microbiol. 25:95-107.

59. Yabuuchi, E., I. Yano, H. Oyaizu, Y. Hashimoto, T. Ezaki, and H. Yamamoto. 1990. Proposals of Sphingomonas paucimobilis gen. nov. and comb. nov., Sphingomonas parapaucimobilis sp. nov., Sphingomonas yanoikuyal sp. nov., Sphingomonas adhaesiva sp. nov., Sphingomonas capsulata comb. nov., and two genospecies of the genus Sphingomonas. Microbiol. Immunol. 34:99-119.

60. Yamada, Y., H. Takinami-Nakamura, Y. Tahara, H. Oyaizu, and K. Komagata. 1982. The ubiquinone systems in the strains of Pseudomonas species. J. Gen. Appl. Microbiol. 28:7-12.

61. Yokota, A. 1989. Taxonomic significance of cellular fatty acid composition in Rhizobium, Bradyrhizobium and Agrobacterium species. IFO Res. Comm. 14:25-39. 